\title{
Supervision of Peer-to-Peer Lending in China
}

\author{
Lin Wang* \\ Zhejiang University \\ Hangzhou, China
}

\begin{abstract}
The development of Internet lending information intermediaries requires the guidance of the legal system. It is necessary to pass laws to define the legal status of online lending information interme diaries. Based on the analysis of the domestic P2P lending operation model and development trend, the author summarizes the risks faced by P2P network lending, and puts forward suggestions from three perspectives: government, platform, and lenders, including effective regulation of the main body and improvement of laws and regulations. The P2P platform needs to fulfill its obligations as an information intermediary, such as information disclosure and investor protection. The government should strengthen supervision and coordination among the central financial regulatory agencies and local financial regulatory agencies so that the government can promote financial innovation while at the same time effectively preventing financial risks. Penetrating supervision measures shall be taken and the responsibilities shall be specified according to the business nature. Industry associations should establish sound industry guidelines and form effective self-regulatory mechanisms, including reputation mechanisms, diversified dispute resolution mechanisms, and industry risk protection funds.
\end{abstract}

Keywords-Administrative Supervision; Self-regulation; Information Disclosure; Investor Protection

\section{INTRODUCTION}

Peer to Peer lending provides a platform for members to borrow money from each other. Individuals who have funds and have financial investment needs use intermediary agencies to help relief information asymmetry. Among them, the intermediary agency is responsible for investigating the credit status of the borrower and charges such as account management fees and service fees. In March 2005, Zopa was established. P2P lending has become very popular abroad and it is seen as an effective solution when some lenders need financial supplements. In China, many small and micro enterprises and individuals are in urgent need of funds for lack of access to bank loan. Without high credit records, it is difficult to obtain loans from financial institutions such as banks. The emergence of the $\mathrm{P} 2 \mathrm{P}$ platform breaks this deadlock ,for P2P platform financing has no requirement for guarantee or mortgage of lenders. Comparatively, applying for a loan with a bank needs to meet strict application conditions and preparation. Also, Lenders and borrowers in different regions can interact with each other through the Internet. As one of the main modes of Internet finance, peer-to-peer lending plays a role of dispersing financial risks ,returning to the essence of finance, and promotes financial inclusion. However, the lack of legislation, lack of supervision, and inadequacy of the credit system make the relevant industries in the industry deviate from the prevailing meaning of inclusive finance. However, the $\mathrm{P} 2 \mathrm{P}$ platforms also generate a series of legal risks when credit risk accumulates and consequently appears as illegal fund-raising and financial fraud. As is often the case, P2P industry has a low threshold of access and in the absence of effective external supervision, the $\mathrm{P} 2 \mathrm{P}$ platform may easily break the law and ethics, illegally engaging in the absorption of deposits in the name of Internet loans .As a consequence, the financial services even turn into illegal fundraising. Some variants of the platform products, such as demolition model, creditor's rights transfer model, selffinancing model and other products may risk meeting the illegal set. The two most crucial factors in the definition of illegal fundraising are: fundraising and social publicity. Therefore, if the P2P platform has capital pool beforehand, it has the risk of being suspected of illegal fundraising. Recently ,the China Banking Regulatory Commission, the Ministry of Industry and Information Technology, the Ministry of Public Security and the State Internet Information Office jointly developed the Interim Measures for the Administration of the Business Activities of Online Lending Information Intermediary Institutions. Firstly, it contains institutional innovation. Secondly it fully affirms the legitimacy of private finance and the legitimacy of online lenders, and further clarifies the boundary between legitimate lending and illegal fundraising. Thirdly, the local government's management of network borrowing was determined and the process of local financial legislation was promoted. [1] To sum up, in order to balance financial innovation and financial security, promote the innovative development of the online lending industry, explore institutional space, and improve regulatory governance, make the following recommendations.

\section{RegUlatory COORDinAtion Mechanism}

In order to establish a dual-class supervision system and improve the regulatory coordination mechanism, there should be a clear division of power between the China Banking Regulatory Commission and provincial government financial supervisory authorities. That is, on the one hand, local financial supervisory departments are responsible for the supervision of institutions in their jurisdictions, including the standardization of guidance, filing management, and risk disposal. On the other hand, the China Banking Regulatory Commission shall formulate a unified supervision plan, be responsible for the daily supervision of the online lending information intermediary agencies, guide the supervision of the local governments, and establish an inter-regional supervision and coordination mechanism. [2]In the future, in order to ensure coordinated supervision of the industry by 
various regulatory agencies, local legislation will be needed first, and the provincial financial office will be the lead agency to gradually improve the coordination mechanism among local regulatory bodies, including: the daily work coordination mechanism, the joint meeting mechanism, and the information Communication mechanism, emergency coordination consultation mechanism, on-site inspection and off-site inspection law enforcement coordination mechanism, etc. Specifically, combine the actual situation of various places and formulate the power of relevant financial planning including internet finance. Timely legislation can provide a legal basis for the power of daily supervision of local government, including market access, crisis management, market withdrawal, information disclosure, risk monitoring, and regulatory ratings.

\section{INFORMATION DISCLOSURE}

The government and lending platform should strengthen information disclosure. At the level of government supervision, it is necessary to strengthen the construction of a financial credit environment, speed up the establishment of a sound social credit system, and establish a trustworthy incentive and disciplinary mechanism . At the level of internet lending intermediary agencies, a sound information disclosure system should be established and adhered to with the principles of authenticity, completeness, accuracy, and timeliness, and there should be no false records, misleading statements, major omissions, or other unfair disclosure practices. The content that online lending platforms should disclose include its own operations, assets, and financial conditions, these affect the lender's choice of whether or not to invest in the company. [3] The disclosed information should include but not be limited to: risk warning information, service charge information, financial indicator information, quarterly reports ,and annual reports. In addition, the $\mathrm{P} 2 \mathrm{P}$ platform often needs to confirm the identity of the transaction between lenders and borrowers. As a result, lenders and borrowers will provide a large amount of personal information, including the identity card ,home addresses, etc. If the site's website security technology is flawed or cracked, it's very easy to face the risk of leakage of personal information. Personal information security need to be emphasized in case of illegally used by P2P platform .At the same time, a confidentiality system should be established. [4]

The negative list management model is an important path embodying the autonomy of private law. It focuses on adopting legal actions to adjust the behavior of market participants, which helps to reduce the risk of new business entry risks, innovation risks, and increases the effectiveness of legal actions. The negative list management model also embodies the principle of statutory authority in public law. It requires that the public authority has the legal basis for the restriction of the rights of any private person. At present, there are some platforms banned from engaging in certain acts. They must not engage in self-financing, collection, lending and other fund raising and lending operations. The time limit must not be split. It is forbidden to engage in the mixed business of agency sales, agency and asset-backed securities of financial products. Based on the logic of the "information platform," the current policy imposes more obligations and bans on the platform, which greatly limits the freedom of commercial entities. The future can be combined with the type of justification principles and be appropriately limited. For example, the provisions on borrowing quotas lack flexibility in type arrangements. [5]The regulatory agencies should take into account the comprehensive platform background, qualifications, business scope, and risk control capabilities to formulate differentiated regulatory limit standards and establish a classified and dynamic quota adjustment mechanism. On the basis of improving the access conditions and operational requirements of the operating enterprise lending business platform, the loan quota for enterprises will be greatly increased.

\section{SELF-REGULATION SYSTEM}

At present, it is necessary to discuss the industry selfdiscipline role of the Internet financial alliance, formulate industry standards in accordance with the actual situation of Internet finance companies, realize the identification of Internet finance companies through the alliance and take the path of directors and members, and eliminate risks. In addition, in addition to administrative supervision, the role of intermediaries and social supervision should also be brought into play. Third-party supervision such as accounting firms, law firms, electronic signature systems, and third-party digital certification agencies should be introduced. As far as social supervision is concerned, it is possible to establish a whistleblowing system, establish a multi-channel whistle-blowing system, punish a certain percentage of irregularities, increase the cost of illegal acts, and strengthen the mechanism of social supervision. While strengthening self-discipline, it is necessary to establish alliance (industry) dispute resolution mechanisms so that the alliance becomes the main channel for handling and reconciling cases or disputes. [6]The Hangzhou Arbitration Commission will be stationed to establish an Internet financial network arbitration to resolve disputes. The coalition needs to closely coordinate the appeals of the coalition, effectively carry out Internet financial enterprise rectification and judicial protection, protect financial innovation, and accurately crack down on the use of Internet financial crimes.

Regulators should establish a record management system and strengthen post-event supervision. In view of the characteristics of innovative and efficient universal inclusion of Internet finance, supervision should follow the concept of "simplifying administration and decentralization, and servicebased supervision," and explore the establishment of a marketoriented financing order based on the logic of marketization. On the one hand, the record management system can reduce administrative intervention and protect innovation. On the other hand, it can also help regulators master the financing dynamics and prevent financial risks. The record management of local financial regulatory agencies does not represent the recognition and evaluation of operational capabilities, compliance levels, and credit status. It only reviews formal requirements and does not undertake substantive review duties and responsibilities. [7]Correspondingly, it is necessary to strengthen post-event supervision to ensure financial security. In industrial and commercial registration, the administrative 
department for industry and commerce needs to specify the business scope of the operator of the network lending platform, clearly define its business scope as an information intermediary, and not engage in any business such as constructing capital pools, absorbing deposits, and issuing loans. Industrial industry information departments need to issue ICP certificates to online loan platforms to ensure information security. The public security department conducts Internet security supervision over business activities and combats financial crimes of online lending. The central financial supervision department and the local financial supervision department must strengthen supervision and coordination and properly handle the registration and filing of Internet finance companies operating across regions. The government needs to form an efficient and perfect filing system and other public disclosure and trust systems, such as information disclosure, information sharing, and information constraints, to promote more open and transparent administrative behavior.

\section{CONCLUSION}

Effective legal path of financial supervision will help regulate and promote the development of internet finance, and form an order of rational competition and benign development in the financial industry. It is essential to strengthen risk prevention and resolution to protect investor rights and interests. The government can use big data supervision to strengthen early warning and monitoring of risks and form a linkage system for pre-, mid- and post-transaction risk control. For specific risk warning and monitoring links, local financial regulatory authorities shall formulate emergency plans for local financial emergencies, including organizational systems, division of responsibilities, prevention and early warning, emergency level, emergency response, and post-processing. The peer-to-peer lending platform should complete the thirdparty custody of funds and achieve fund segregation, and set up separate accounts for the self-owned funds of the network lending information intermediary and the borrower's funds. The platform should improve its governance structure and internal control mechanisms, establish business rules and management systems such as risk management, internal control, risk concentration, related transactions, and asset liquidity, establish a sound corporate governance structure in accordance with the requirements of the "Company Law".
[8]It is necessary to clarify the relationship of powers and responsibilities between supervisors and managers, formulate sound and effective rules of procedure, decision-making procedures and internal audit systems. Industry self-regulatory organizations should strengthen investor education, create multiple dispute resolution mechanisms, and implement the principle of risk contingency based on investors' ability to identify risks and affordability. [9]The industry self-regulatory organization can establish a mediation mechanism, an investor opinion search mechanism, and strengthen links with local judicial organs, arbitration, mediation, and other organizations, and build multiple dispute resolution mechanisms such as Internet arbitration, third-party mediation, and online dispute resolution. Finally, industry associations should guide the establishment of investor protection funds and risk protection funds similar to the deposit insurance system to protect investor rights and realize risk compensation.

\section{REFERENCES}

[1] Wang Li, “Access Control of Internet Financing Platforms,” Securities Law Review,” pp.390,2016.(In Chinese)

[2] Wang Liming, "Negative List Management Model and Private Law Autonomy," Journal of Chinese Legal Science, pp.31, May 2014. (In Chinese).

[3] Xie Erman, Huang Xu, "The Basic Logic and Thinking of P2P Industry Supervision in China,” Tsinghua Financial Review,pp.96,February 2016.(In Chinese)

[4] Sun Yanjun, "Based on the Legal Nature of the Variation of Business Model to Set Up the P2P Financial Supervision Mode," Journal of Central University of Finance and Economics, pp. 45, March 2016.(In Chinese)

[5] Zhang Shaohua, "Local Supervision on Peer-To-Peer Lending Platform,” Journal of Internet Finance,” pp.70,July 2016.(In Chinese)

[6] Kang Yumei, "Government's role in the P2P network lending and system response,” Oriental Law Review, pp.89, February 2015. (In Chinese)

[7] Jack R. Magee, "Peer-to-Peer Lending in the United States: Surviving after Dodd-Frank,” North Carolina Banking Institute, pp170, March, 2011.

[8] Eric C. Chaffee \& Geoffrey C.Rapp, "Regulating Online Peer-to-Peer Lending in the Aftermath of Dodd-Frank: In Search of an Evolving Regulatory Regime for an Evolving Industry”, WASH.\&LEE L.REV. vol.69, pp509, 2012.

[9] He Jianfeng, “On the Legal Paths to the Internet Financial Regulation of Our Country” Jinan Journal, pp.60,January 2016.(In Chinese) 